\title{
Wildflower areas within revitalized agricultural matrices boost small mammal populations but not breeding Barn Owls
}

\author{
Raphaël Arlettaz $\cdot$ Markus Krähenbühl • \\ Bettina Almasi • Alexandre Roulin · \\ Michael Schaub
}

Received: 6 August 2009/Revised: 10 December 2009/Accepted: 11 December 2009/Published online: 8 January 2010

(C) Dt. Ornithologen-Gesellschaft e.V. 2010

\begin{abstract}
Agro-ecosystems have recently experienced dramatic losses of biodiversity due to more intensive production methods. In order to increase species diversity, agri-environment schemes provide subsidies to farmers who devote a fraction of their land to ecological compensation areas (ECAs). Several studies have shown that invertebrate biodiversity is actually higher in ECAs than in nearby intensively cultivated farmland. It remains poorly understood, however, to what extent ECAs also favour vertebrates, such as small mammals and their predators, which would contribute to restoring functional food chains within revitalised agricultural matrices. We studied small mammal populations among eight habitat types-including wildflower areas, a specific ECA in Switzerland-and habitat selection (radiotracking) by the Barn Owl Tyto
\end{abstract}

Communicated by F. Bairlein.

R. Arlettaz $(\bowtie) \cdot$ M. Krähenbühl · M. Schaub

Division of Conservation Biology, Institute of Ecology

and Evolution, University of Bern, Baltzerstrasse 6,

3012 Bern, Switzerland

e-mail: raphael.arlettaz@iee.unibe.ch

R. Arlettaz

Swiss Ornithological Institute, Valais Field Station,

Nature Centre, 3970 Salgesch, Switzerland

\section{R. Arlettaz}

The Ecology Centre, University of Queensland,

St Lucia, QLD 4072, Australia

B. Almasi · M. Schaub

Swiss Ornithological Institute, 6204 Sempach, Switzerland

A. Roulin

Department of Ecology and Evolution, University of Lausanne,

1012 Lausanne, Switzerland alba, one of their principal predators. Our prediction was that habitats with higher abundances of small mammals would be more visited by foraging Barn Owls during the period of chicks' provisioning. Small mammal abundance tended to be higher in wildflower areas than in any other habitat type. Barn Owls, however, preferred to forage in cereal fields and grassland. They avoided all types of crops other than cereals, as well as wildflower areas, which suggests that they do not select their hunting habitat primarily with respect to prey density. Instead of prey abundance, prey accessibility may play a more crucial role: wildflower areas have a dense vegetation cover, which may impede access to prey for foraging owls. The exploitation of wildflower areas by the owls might be enhanced by creating open foraging corridors within or around wildflower areas. Wildflower areas managed in that way might contribute to restore functional links in food webs within agro-ecosystems.

Keywords Ecological compensation areas .

Agro-ecosystems - Small mammals $\cdot$ Species conservation

\section{Introduction}

During the past decades, flora and fauna within agricultural ecosystems have been radically impoverished due to more intensive production methods (Donald et al. 2001; Benton et al. 2003; Britschgi et al. 2006). Simplification of crop rotations, larger fields, loss of ecological relevant structures caused by land consolidation and widespread use of agrochemicals have led to a dramatic decline in plant and animal species richness (Schmid 2002). In order to improve the state of biodiversity in farmland, several countries have adopted agri-environment schemes. Their efficacy has been 
vigorously debated and is still controversial, especially with respect to some groups of vertebrates, although benefits for some invertebrates seem indisputable (Nentwig 2000; Kleijn et al. 2001, 2006; Kleijn and Sutherland 2003; Knop et al. 2006; Aschwanden et al. 2007).

Interestingly, agri-environment schemes are primarily considered as biodiversity promoters (e.g. Kleijn and Sutherland 2003; Knop et al. 2006; Whitthingham 2007). Until very recently, their role in enhancing biomass along food chains has not been a major focus of research (Shore et al. 2005; Aschwanden et al. 2007; Askew et al. 2007; MacDonald et al. 2007; Reid et al. 2007). This is surprising because ecosystem functionalities largely depend upon major fluxes of biomass and energy from the lower to the upper trophic levels; a few dominant producer and consumer species usually constitute the basic architecture of an ecological community. As such, the presence of abundant populations of these dominant taxa often remains the best predictor of predator occurrence and breeding success (e.g. Hansson and Henttonen 1988; Korpimäki and Norrdahl 1991; Veit et al. 1993; Reid and Croxall 2001; Gilg et al. 2003, 2006; Palma et al. 2006). As a result, favouring the abundance of common species at lower trophic levels may eventually be crucial for promoting biodiversity as a whole, since the existence of good prey reservoirs will contribute to attract their predators, i.e. a symbolic "flagship" fraction of species diversity. Agri-environment schemes must restore agricultural landscape matrices in such a way that predators, which were first to vanish after the dramatic land use intensification, progressively reappear in farmland. In doing so, agri-environment schemes would contribute to the recovery of functional links in food webs within agro-ecosystems.

Ecological compensation areas (ECAs) have become major elements of agri-environment schemes in several countries of the European Union, totalling $€ 24$ billion of subsidies for the period 1994-2003 (Kleijn and Sutherland 2003; Askew et al. 2007). In Switzerland, for instance, farmers can only receive federal agricultural subsidies if $7 \%$ of their land is designated as an ECA. Swiss ECAs contain, among other habitats, extensive meadows and wildflower areas (Schweizer Eidgenossenschaft 1998). Such ECAs may enhance the diversity and richness of plants and some insects, but the evidence for benefits remains controversial for several groups of arthropods such as spiders and for most vertebrates (Kleijn et al. 2006; Birrer et al. 2007). Wildflower areas are a kind of "managed" set-aside in the sense that seeds of wild flowers are sown by farmers whereas some invasive weeds are controlled through targeted, plant-by-plant herbicide application. To our knowledge, they have no equivalent in other European agri-environment schemes, although they look similar to set-aside and fallowland from a vegetation structural viewpoint. In Switzerland, wildflower areas represent only $2 \%$ of the ECAs (3,700 ha in total in 2004), but have become obvious features of modern farmland due to their high flower species richness that renders them especially attractive for the public. These ECAs have been shown to enhance "beneficial" organisms (e.g. Revaz et al. 2008) and also the abundance of agricultural pests such as voles (Microtus spp.; Tattersall et al. 1997, 2000; Briner et al. 2005; Aschwanden et al. 2007). Small mammals exploit wildflower areas preferentially because they offer a high food supply and a dense vegetation cover that protects them from predators (Wakeley 1978; Baker and Brooks 1981; Bechard 1982; Dickman et al. 1991; Jacob and Hempel 2003; Aschwanden et al. 2007). In the present study, we attempted to quantify small mammal population densities in different habitats, including wildflower areas, and to study patterns of habitat selection in one of their major nocturnal predators, the Barn Owl Tyto alba. We tested whether wildflower areas may favour small mammals and their vertebrate predators, thereby contributing to restore functional links along the food chain in agricultural ecosystems.

The Barn Owl has a wide distribution range (Mebs and Scherzinger 2000). In temperate biomes, it has followed the spread of agriculture as it hunts small mammals such as microtid rodents and shrews mostly in open and semi-open habitats (Snow and Perrins 1998). There has been a widespread decline of the Barn Owl in the twentieth century due to intensification of farming practices and habitat loss, including shortage of suitable breeding sites (Snow and Perrins 1998; Mebs and Scherzinger 2000; Mebs and Roulin 2002; Altwegg et al. 2006; Askew et al. 2007). The species is near endangered in Switzerland (Burkhardt and Schmid 2001) with an estimated 1,000-1,500 breeding pairs (Schmid et al. 1998). Local density may reach up to 42 pairs per $100 \mathrm{~km}^{2}$ in suitable farmland and with a good availability of nest-boxes (Roulin 1999). Swiss populations fluctuate in synchrony with vole populations (Roulin 2002) as is the case for many avian predators (Korpimäki 1994).

The present study addresses two main questions: (1) is the abundance of small mammals higher in wildflower areas than in other agricultural and nearby habitats? and (2) if so, do Barn Owls spend a disproportionate fraction of time hunting in wildflower areas compared to other habitats, and is this reflected in subsequent productivity of breeding pairs? We use the information to assess the extent to which Barn Owls benefit from wildflower areas designed to revitalise the agricultural matrix.

\section{Materials and methods}

The fieldwork was conducted in the region around Payerne in Western Switzerland, a $190-\mathrm{km}^{2}$-wide plain bordered by 
a hilly landscape $\left(46^{\circ} 43-56^{\prime} \mathrm{N}, 6^{\circ} 49^{\prime}-7^{\circ} 02^{\prime} \mathrm{E}, 434-650 \mathrm{~m}\right.$ elevation). Intensive agriculture is the dominant land use in the area. The most important crops on the plain are cereals (mostly winter wheat Triticum aestivum), maize Zea mays, sugar beet Beta vulgaris, and tobacco Nicotiana tabacum. On the lower hill slopes, there is some viniculture, whereas the hills themselves are mainly used for dairy farming. Wildflower areas are scattered across the study area. The region supports a relatively high population density of Barn Owls (e.g. Altwegg et al. 2003, 2007).

\section{Density of small mammals}

For estimating small mammal abundance, we selected four study sites which all included the eight following habitat types in close proximity: (1) wildflower areas that were $>2$ years old (because in $>2$ years old wildflower strips vole abundance is no longer related to age; Tattersall et al. 2000) and had a size of $>1$ ha to minimise edge effects which may influence local densities of small mammals; (2) banks of canals and ditches; (3) edges of forests or hedgerows; (4) fields of winter wheat; (5) maize; (6) tobacco; (7) extensive meadows that had not been ploughed for at least 5 years (permanent meadow); and (8) intensively fertilised grassland that is part of the crop rotation (intensive meadow).

We used three trap types (Longworth, Penlon, Abingdon, UK; Sherman, H.B. Sherman Traps, Tallahassee, USA; Trip Trap, Alana Ecology, Bishops Castle, UK) and always placed three traps, one of each type, at capture locations. As bait, pieces of carrots and cheese as well as grains (Hamster food from Coop, $\mathrm{CH}$ ) were used (Briner et al. 2005). Additionally, a handful of hay was put into the traps to enhance survival of the animals captured (Briner et al. 2005).

Capture design followed that of Aschwanden et al. (2005, 2007) who also investigated small mammals in agro-ecosystems. We applied a capture-mark-recapture protocol to estimate population sizes in May, July and September 2005. In each habitat, traps were placed in a reticulated pattern with distances of $5 \mathrm{~m}$ between trap sets along two parallel 45-m-long transects. This design defines 20 trap points, totalling 60 traps per sampled habitat. Assuming a capture radius of ca. $5 \mathrm{~m}$ around traps, the overall catching area of each study plot was about $825 \mathrm{~m}^{2}$. Traps were set over a period of three nights and days and were visited every $8 \mathrm{~h}$. We installed them at 1400 hours on day 1 and removed them at 0600 hours on day 4 . The number of traps available ( $n=240$ in total) and the handling time allowed us to set traps in four habitat types per site simultaneously $(4 \times 60=240$ traps $)$. After trapping in these first four habitat types (randomised habitat sequence), the same procedure was immediately repeated in the four other habitat types at the same study site. Thus, one complete capture series at one study site (each site comprising the eight different habitat types mentioned above, i.e. eight study plots) lasted 7 days in a row. At each visit, small mammals were identified, sexed, aged, weighed and marked. Marking consisted of local cutting of the fur on the back and the head at seven different places to make the darker underfur visible. Varied cutting codes enabled individual recognition. Subsequent trap checks enabled a capture history to be constructed for each animal. We found no movement of individuals between the habitat types sampled at each study site.

Because the populations were likely to be demographically and geographically closed during the short sampling period $(72 \mathrm{~h})$, we used closed population models implemented in the program "Capture" to estimate population sizes (Otis et al. 1978). Because of the closure, the only parameters to be estimated are capture rates and the population size. We fitted eight models to each dataset that used different structures for the capture rates. Capture rates were allowed to be constant, to be variable across time, to change in response to whether or not an individual has been captured previously, to be individually different, and combinations thereof (Otis et al. 1978). For each month, habitat type and site, the best fitting model was chosen (Appendix). When no individual was recaptured, population size could not be estimated with the closed population models. In these cases, we used the number of captured individuals as the minimal population size. We calculated the mammal density ( $n / \mathrm{ha}$, with the catching area of $825 \mathrm{~m}^{2}$ as the reference area) for each study plot and tested whether habitat type and study site explained the variance between plots using repeated measures ANOVA (JMP 4.0.4; SAS Institute, Cary, NC, USA) on the ranks of densities. As densities were sampled in equal time intervals throughout the season, the three consecutive capture series (May, July, September) were considered as repeated measures, providing information about temporal trends. $P$ values are two-tailed with rejection levels set at 5\%. Differences in densities were finally tested with posthoc pairwise comparisons with respect to habitat type and season (Tukey-Kramer HSD test).

\section{Habitat selection}

Seven breeding male owls were radio-tagged for the study of habitat selection; we selected birds nesting in the vicinity of the small mammal capture sites, but owl nests were well scattered throughout the study area. The owls were caught and tagged with radio transmitters (ATS type A1240, 8 g, mortality sensor: 6 h fast; ATS, Isanti, USA, fixed with a Rappole leg-harness with a rubber band that falls off after 1 year). Owls were radio-located using a 
portable receiver (Telonics TR-5; Telonics; Mesa AZ, USA), and a hand-held 3-element Yagy antenna.

Radiotracking lasted from June to September 2005 with interruptions during the small mammal capture sessions (see above). We tracked only males, since this sex is the main food provider to Barn Owl broods (Roulin et al. 2001). The tagged owls were radiotracked from a car and located by the "homing-in" on the animal method described by White and Garrot (1990). Visual localisations were attempted in open areas, using an observation spyglass (Aspectem 80/500 with vario ocular; Docter, Eisfeld, Germany), a powerful torch (Maglite; Mag Instrument, Ontario, USA), and a GPS device (eTrex Gecko; Garmin International, Olathe, USA).

Positions of hunting or resting owls were obtained from GPS readings. Commuting activity (rapid flight between areas) was not part of the dataset used for analysis, which focused only on actual foraging activity (i.e. activity concentrated on a given area). The time, behaviour (sitting/ flying), hunting activity ("dives" to the ground) and habitat type of all observations were also recorded. Bearings were used to draw home ranges as minimum convex polygons (MCP; Mohr 1947). These MCPs were mapped in the field for estimating agricultural land-use (habitat types and linear features, see below). MCPs were divided into 1-ha squares according to the official reference grid of the Swiss Federal Topographic Service (Arlettaz 1999). For each 1ha grid cell, we noted the dominant habitat type in the cell (cereals, maize, tobacco, other crops, grassland, forest, wildflower area, riparian and settlement). Wildflower areas were often present in the form of strips, i.e. too small to be the dominant habitat type in a square of $1 \mathrm{ha}$. We therefore also recorded all 1-ha cells containing wildflower strips. The length of different linear structures (forest edges, rivers, ditches, wildflower strips, hedgerows and total linear structures) was also estimated for each 1-ha cell (0: no linear structure; $1: 0-25 ; 2: 25-50 ; 3: 50-75 ; 4: 75-100$; 5: $>100 \mathrm{~m})$

Radiotracking data allowed distinguishing between visited and non-visited 1-ha grid cells within individual home ranges (MCPs). We assumed that visited cells mirrored habitat preferences, whilst non-visited cells were avoided because they represented non-suitable habitat. This assumption is realistic since every cell in the MCP was potentially overflown by the owl. This approach has been used with success in other studies (e.g. Arlettaz 1999).

For habitat selection analysis at the population level, we conducted a Compositional Analysis (Aebischer et al. 1993) to test for differences between used and available habitat (the latter obtained from all 1-ha cells across individual MCPs; Aschwanden et al. 2005). This non-parametric technique takes into account that the proportional use of one habitat type is dependent on that of other habitat types (Aebischer et al. 1993). Compositional Analysis enables the examination of only $n-1$ factors, with $n$ being the number of individuals considered. Our basic habitat matrix had thus to be reduced to six parameters: maize, tobacco and other crops were grouped together as cropland, whereas settlements were excluded. According to Aebischer et al. (1993), zero values in the "used" worksheet were replaced by a small number (0.001).

Because Compositional Analysis was only appropriate to study habitat selection at the population level (although through the individuals), we used alternative statistical methods to test for individual preferences. Frequency distributions of visited versus non-visited cells were computed through randomised contingency table procedures with the program Actus2 (G. F. Estabrook, University of Michigan, Ann Arbor, MI 48109-1048, USA; Estabrook and Estabrook 1989; Arlettaz 1999). This program provides levels of probability for any positive or negative deviation between observed and expected frequencies, showing habitat selection patterns for each individual owl and the nine habitat types. Comparing selection trends among the seven individuals also enabled us to draw information on general habitat selection pattern. For that purpose, we developed an ad hoc selection index by subtracting for each habitat type the percentage of owls that avoided that habitat from the percentage of owls that showed positive selection.

To further assess a possible effect of wildflower areas and strips, we used randomised contingency table procedures (as above), testing for differences for each owl separately, between the frequency distribution of visited and non-visited cells in presence or absence of that habitat.

For a comparison of linear features (structural length) between visited and non-visited cells, we relied on nonparametric statistics because the variables were not normally distributed and could not be transformed appropriately (two-tailed, Wilcoxon-Kruskal-Wallis Test; program JMP 4.0.4; SAS Institute).

Reproductive output versus home range size and habitat characteristics

The relationship (Spearman rank correlation) between reproductive parameters and habitat structure in radiotracked owls was considered in two ways. First, we examined whether there was a relationship between home range size and availability of suitable foraging habitats within an individual home range, predicting smaller home range sizes where the proportion of suitable habitat was high. Second, we tested whether breeding performance (clutch size and number of fledglings) correlated with home range size and/or proportion of suitable foraging habitat within the home range, predicting higher productivity where habitat conditions were more favourable (i.e. 
small home range and high foraging habitat quality). Given the unilateral direction of these predictions, correlation tests were one-tailed.

\section{Results}

Density of small mammals

During three sampling sessions in May, July and September, we captured 1,286 small mammals, including 224 recaptures (17.4\%; Fig. 1). In total, we thus examined 1,062 individuals, of which 1,035 could be identified to one of the following eight species: Apodemus sylvaticus $(n=329)$, Microtus arvalis $(n=316)$ and A. flavicollis $(n=261)$ largely dominated the sample, followed by Clethrionomys glareolus $(n=74)$, Crocidura russula $(n=33)$, Sorex araneus/S. coronatus $(n=19)$, Mus

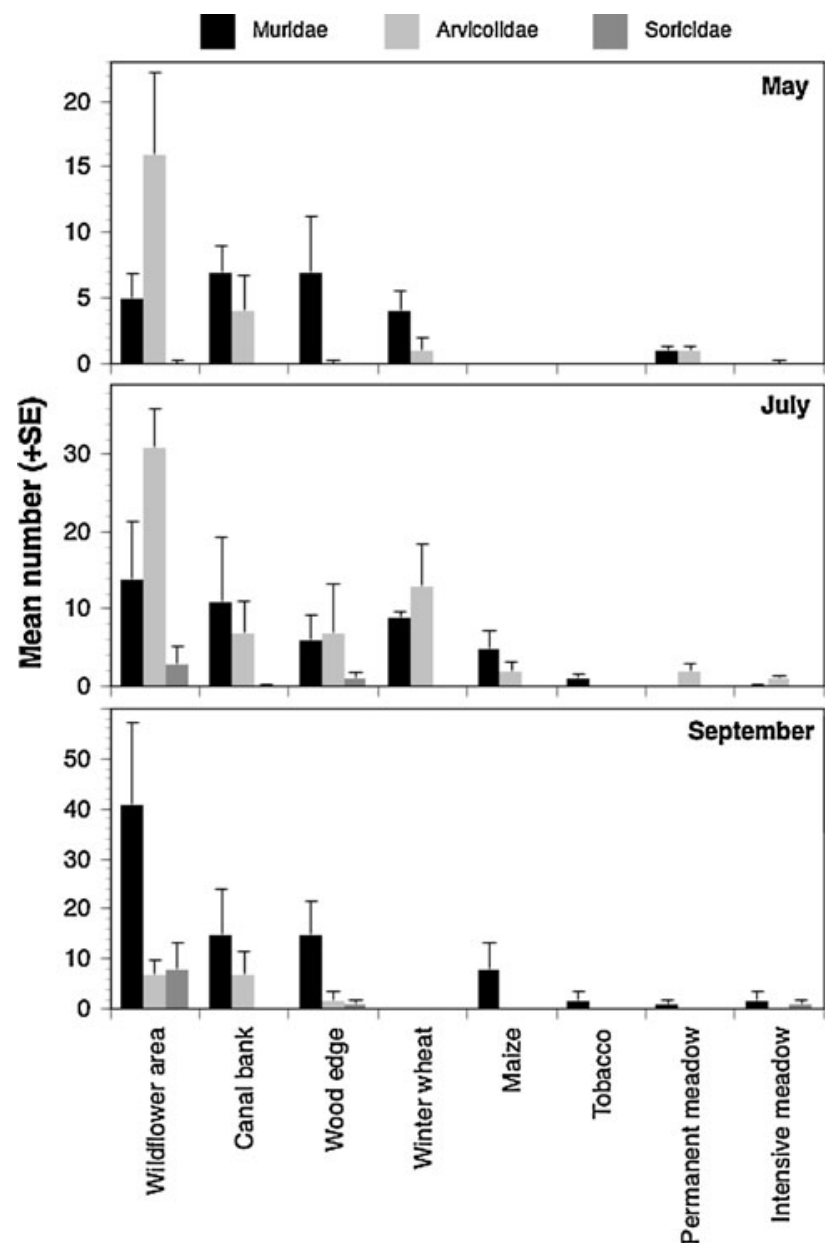

Fig. 1 Mean (+SE, showing the variation between study sites) number of rodents (Muridae, Arvicolidae) and shrews (Soricidae) caught with pitfalls in May, July and September at four sites within each habitat type musculus $(n=2)$ and Arvicola terrestris $(n=1)$. Species abundance varied with respect to habitat type (Fig. 2), but the three most common species dominated in all habitats. Species richness was highest in wildflower areas with six species (A. flavicollis, A. sylvaticus, C. russula, M. arvalis, $M$. musculus and $S$. araneus/S. coronatus), followed by canal bank and wood edge, each with five species (A. flavicollis, A. sylvaticus, C. glareolus, M. arvalis and $S$. araneus/S. coronatus at canal bank, and $C$. russula at wood edge; Figs. 1 and 2). The poorest species habitat type was tobacco with only two species (A. flavicollis and A. sylvaticus). The efficacy of traps differed slightly among types, with 457 captures in Trip-Traps, 441 in Longworth traps and 388 in Sherman traps $\left(\chi^{2}=6.211, d f=2\right.$, $P=0.045$ ).

Densities of small mammals varied significantly between habitat types $\left(F_{1,8}=195.69, \quad P<0.0001\right)$, throughout the season $\left(F_{1,2}=7.47, P<0.0001\right)$, and

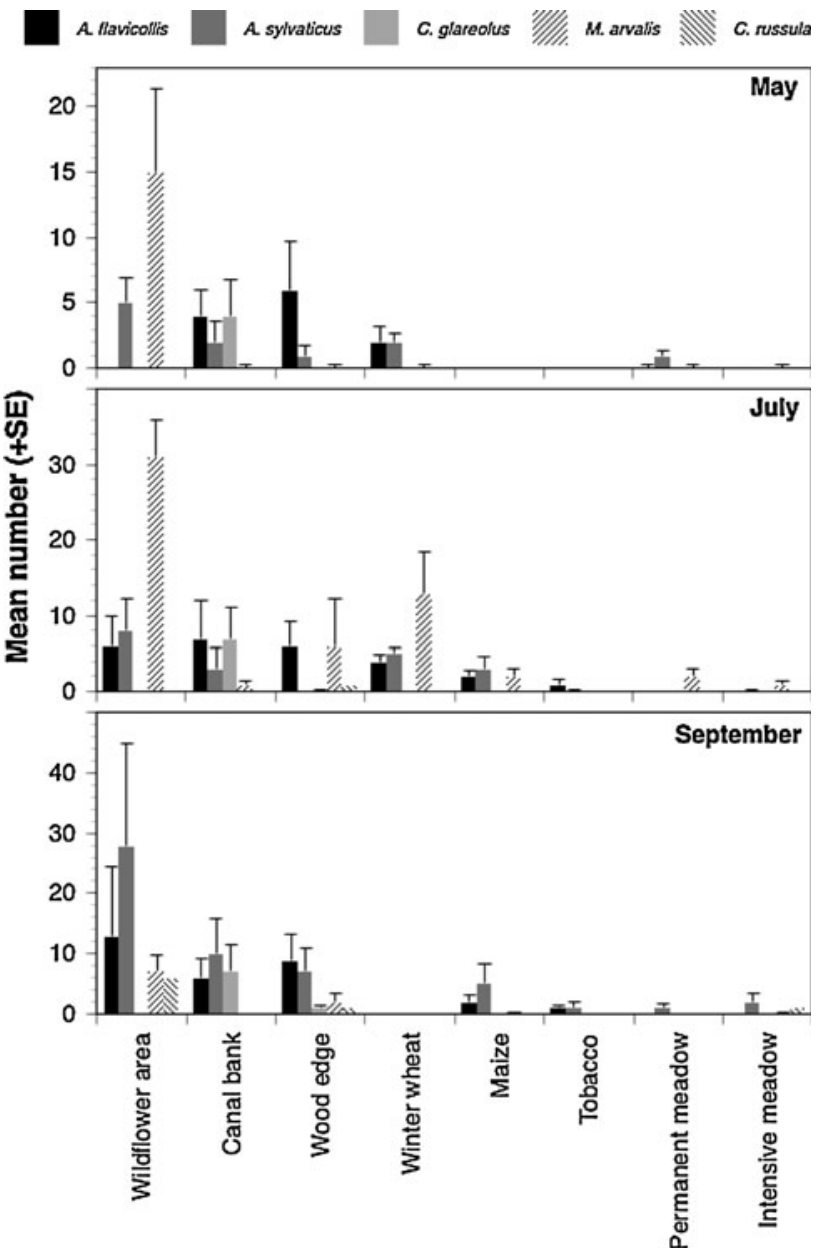

Fig. 2 Mean (+SE, showing the variation between study sites) number of dominant species of rodents and shrews caught in May, July and September at four study sites within eight different habitat types 
between study sites $\left(F_{1,4}=1.66, P=0.0001 ; \mathrm{Fig} .3\right)$. The highest average densities in all 3 months were within wildflower areas (mean \pm SE: $458 \pm 189,1,030 \pm 133$ and 1,285 \pm 440 individuals per hectare in May, June and September, respectively). The highest density recorded was in a wildflower area with an estimated 1,976 $( \pm 75)$ individuals per hectare in September. In May, small mammal densities were significantly higher in wildflower areas, canal banks and winter wheat $(P<0.05$; Tukey-Kramer HSD) than in maize, tobacco, permanent (for wildflower areas only) and intensive meadows. Densities were also higher in woodland edges than in maize and tobacco. In July, densities were significantly higher in wildflower areas and winter wheat than in tobacco or permanent and intensive meadows, while in September they were only significantly higher in wildflower areas than in winter wheat (Fig. 3).

To sum up, species richness and densities of small mammals varied significantly between habitat types, but in

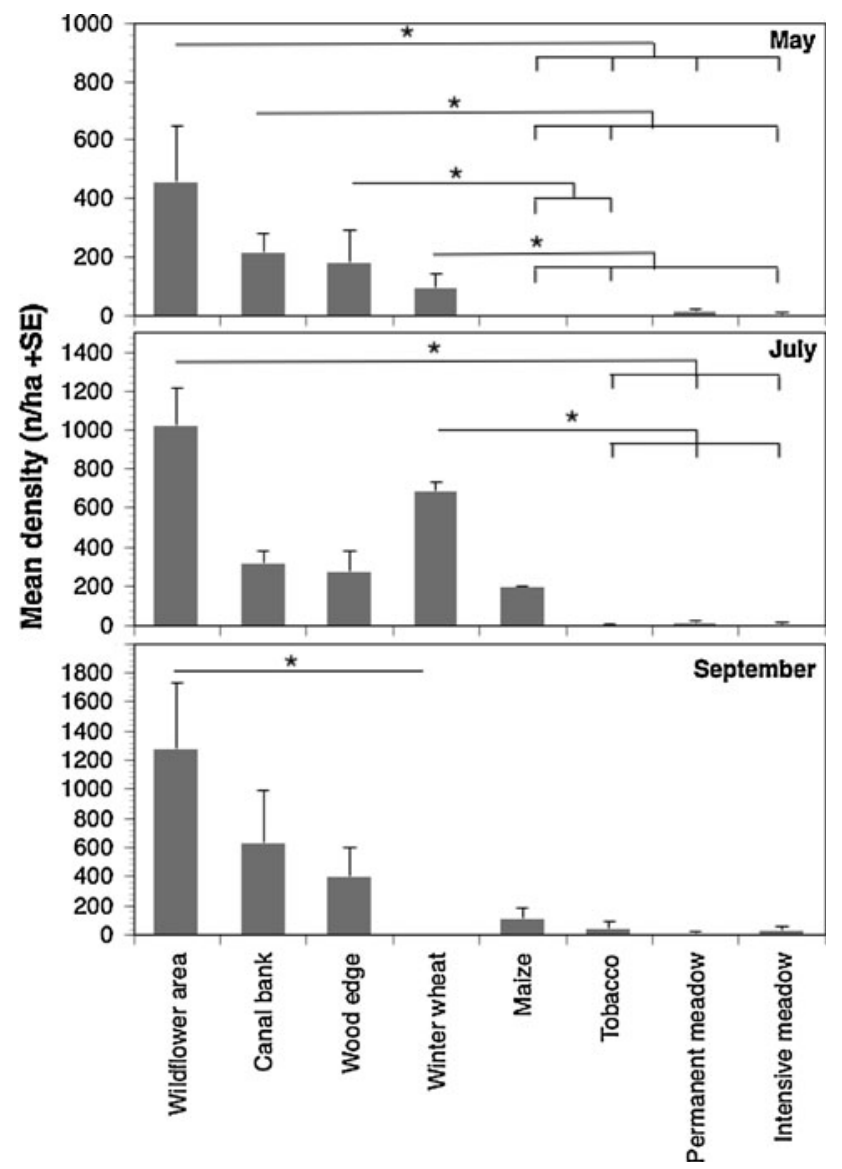

Fig. 3 Mean densities of small mammals $(n /$ ha + SE, showing the variation among the four study sites) in eight habitat types in May, July and September. Asterisks indicate significant differences $(P<0.05$, Tukey-Kramer post hoc pairwise comparison $)$ general wildflower areas were supporting consistently higher numbers of species and individuals throughout the trapping season.

Habitat selection

A total of 158 precise localisations of the seven foraging male Barn Owls were obtained (mean \pm SD: $22.6 \pm 5.8$, range 17-34). There was a large variance in individual home range size (mean $335.6 \pm 234.2$ ha, median 297 ha; range 93-804 ha; Table 1). Compositional Analysis at the population level suggested that habitat types were not chosen at random $\left(\lambda=0.07, \chi^{2}=18.58, P=0.0023\right)$. In particular, cereals (winter wheat) were significantly preferred over crops (other than cereals and maize), this relative to availability (Table 2).

The randomised contingency table analyses run on the individuals separately are presented in Table 3 . Our ad hoc index of habitat selection suggests the following decreasing order in habitat preferences: cereals $>$ grassland $>$ forest, settlement $>$ riparian $>$ tobacco $>$ maize, other crops $>$ wildflower areas (Table 3).

That wildflower areas ranked low in foraging habitat preferences (the two above analyses; Tables 2 and 3) was further supported by the fact that two owls showed a significant difference in the frequency distribution of this habitat between visited and non-visited cells: both avoided this habitat (randomised contingency tables, $P<0.05$; Table 4).

The comparison of structural length of linear habitat features showed that there were few consistent patterns of selection: only two owls showed preference for 1-ha cells with longer streams and hedgerows (Table 5). A third individual showed a marginal preference for longer forest edge $(P=0.08$; Table 5).

A total of 24 hunting events $(n=4$ birds) were observed visually: 22 (92\%) of these were of owls searching for prey on the wing, patrolling in flight above foraging grounds, and only 2 cases $(8 \%)$ were of owls perch-hunting.

Reproductive output versus home range size and habitat characteristics

There was a negative relationship between home range size and proportion of preferred foraging habitat (grassland and cereals) within individual home ranges (Spearman rank correlation, $\left.r_{\mathrm{s}}=-0.714, n=7, P=0.044\right)$, suggesting that male Barn Owls tended to compensate for low habitat suitability by increasing territory size. Increasing home range size, or lack of suitable foraging habitat, seems to bear costs: both clutch size (range 5-9, $r_{\mathrm{s}}=-0.674, n=7$, $P=0.049$ ) and number of fledglings (range 4-6) 
Table 1 Synopsis of radiotracking sessions carried out with seven male Barn Owls Tyto alba in summer 2005

\begin{tabular}{|c|c|c|c|c|c|c|c|c|}
\hline Individual \# & $\begin{array}{l}\text { Radiotracking } \\
\text { period }\end{array}$ & $\begin{array}{l}\text { Number of nights } \\
\text { with effective } \\
\text { tracking }\end{array}$ & $\begin{array}{l}\text { Number of } \\
\text { bearings }\end{array}$ & $\begin{array}{l}\text { Number of } \\
\text { visited } 1 \text {-ha } \\
\text { squares }\end{array}$ & $\begin{array}{l}\text { Visually } \\
\text { observed hunting } \\
\text { events }\end{array}$ & $\begin{array}{l}\text { Foraging home } \\
\text { range (ha) (MCP) }\end{array}$ & $\begin{array}{l}\text { Clutch } \\
\text { size }\end{array}$ & $\begin{array}{l}\text { Number of } \\
\text { fledglings }\end{array}$ \\
\hline 1 & $07.06-26.06 .05$ & 11 & 39 & 26 & 4 & 211 & 7 & 6 \\
\hline 2 & 07.06-15.08.05 & 8 & 19 & 17 & 3 & 93 & 6 & 6 \\
\hline 3 & $27.06-27.07 .05$ & 14 & 28 & 22 & 4 & 804 & 5 & 4 \\
\hline 4 & $04.08-10.08 .05$ & 7 & 24 & 21 & 0 & 380 & 5 & 4 \\
\hline 5 & $10.08-06.09 .05$ & 14 & 22 & 20 & 0 & 214 & 6 & 5 \\
\hline 6 & $12.08-06.09 .05$ & 14 & 19 & 18 & 0 & 419 & 5 & 5 \\
\hline 7 & $15.08-26.08 .05$ & 7 & 35 & 34 & 13 & 228 & 9 & 5 \\
\hline Total & & 75 & 186 & 158 & 24 & & & \\
\hline
\end{tabular}

MCP Minimum convex polygon

Table 2 Results of compositional analysis pinpointing differences in habitat selection of seven male Barn Owls

\begin{tabular}{|c|c|c|c|c|c|c|c|}
\hline & Cereals & Crops & Grassland & Wildflower area & Forest & Riparian & Rank \\
\hline Cereals & & +++ & + & + & - & + & 4 \\
\hline Crops & --- & & - & + & - & + & 2 \\
\hline Grassland & - & + & & + & - & + & 3 \\
\hline Wildflower area & - & - & - & & - & - & 0 \\
\hline Forest & + & + & + & + & & + & 5 \\
\hline Riparian & - & - & - & + & - & & 1 \\
\hline
\end{tabular}

Signs indicate directions in pairwise habitat preferences $(+)$ and avoidances $(-)$ when reading the table line after line (e.g. cereals preferred over crops, grassland, etc.). Three symbols express a significant difference $(P<0.05)$; one symbol indicates a trend. The rank shows the order of preferred (high values) versus avoided (low values) habitats

Table 3 Habitat selection index (see text for details about calculation) estimated from randomised contingency tables obtained from seven male Barn Owls

\begin{tabular}{|c|c|c|c|c|c|c|c|c|c|}
\hline Owl & Cereals & Grassland & Forest & Settlement & Riparian & Tobacco & Maize & Other crop & Wildflower area \\
\hline 1 & + & - & NS & - & + & + & NS & - & - \\
\hline 2 & + & NS & - & NS & 0 & - & NS & NS & NS \\
\hline 3 & + & NS & NS & NS & NS & - & NS & - & + \\
\hline 4 & - & + & NS & + & - & - & - & NS & - \\
\hline 5 & NS & NS & + & + & + & 0 & - & + & NS \\
\hline 6 & NS & NS & 0 & NS & - & + & NS & NS & NS \\
\hline 7 & NS & + & 0 & - & - & 0 & NS & - & - \\
\hline Index & $+29 \%$ & $+14 \%$ & $0 \%$ & $0 \%$ & $-17 \%$ & $-20 \%$ & $-29 \%$ & $-29 \%$ & $-33 \%$ \\
\hline
\end{tabular}

For every owl, the probability of a deviation between visited and non-visited 1-ha squares for a given habitat type is indicated: + shows a significant positive selection; - a significant negative selection; NS no significant selection pattern; 0 not available

correlated negatively with home range size $\left(r_{\mathrm{s}}=-0.850\right.$, $n=7, P=0.015)$.

\section{Discussion}

This study suggests that the abundance of small mammals, which varied markedly between habitat types, is not the principal factor dictating habitat selection patterns in the Barn Owl: the habitats offering the highest densities of prey, especially wildflower areas, were avoided during foraging. This discrepancy is most probably due to the fact that it is prey detectability and/or accessibility and not prey density which ultimately defines its availability for the owls. This pattern has been found in several species of birds inhabiting farmland (reviewed in Atkinson et al. 
Table 4 Comparison of the frequency distribution of wildflower areas and strips between visited and non-visited 1-ha cells within the individual home ranges of seven male Barn Owls (randomised contingency table procedures)

\begin{tabular}{|c|c|c|c|c|c|}
\hline \multirow[t]{2}{*}{ Owl } & \multicolumn{2}{|l|}{ Visited } & \multicolumn{2}{|l|}{ Non-visited } & \multirow[t]{2}{*}{ Randomisation } \\
\hline & Wildflower & No wildflower & Wildflower & No wildflower & \\
\hline 1 & 2 & 21 & 21 & 164 & NS \\
\hline 2 & 0 & 17 & 0 & 76 & Not applicable \\
\hline 3 & 1 & 21 & 42 & 740 & NS \\
\hline 4 & 1 & 20 & 27 & 332 & NS \\
\hline 5 & 3 & 17 & 23 & 171 & NS \\
\hline 6 & 0 & 18 & 3 & 398 & $*$ \\
\hline 7 & 0 & 34 & 7 & 187 & $*$ \\
\hline
\end{tabular}

NS non-significant selection

* Significant avoidance $(P<0.01)$

Table 5 Differences between average $(\overline{\mathrm{X}} \pm \mathrm{SD})$ estimated structure lengths $(0$ : no such linear structure; $1: 1-25 ; 2: 25-50 ; 3: 50-75 ; 4: 75-100$; 5: $>100 \mathrm{~m})$ in visited versus non-visited 1-ha cells in the home ranges of seven male Barn Owls

\begin{tabular}{|c|c|c|c|c|c|c|c|c|c|c|c|c|c|c|c|c|c|c|c|c|c|}
\hline \multirow[t]{3}{*}{ Owl } & \multicolumn{7}{|c|}{ Forest edge length } & \multicolumn{7}{|c|}{ Stream length } & \multicolumn{7}{|c|}{ Wildflower strip length } \\
\hline & \multicolumn{3}{|c|}{ Used } & \multicolumn{3}{|c|}{ Unused } & \multirow[t]{2}{*}{$P$} & \multicolumn{3}{|c|}{ Used } & \multicolumn{3}{|c|}{ Unused } & \multirow[t]{2}{*}{$P$} & \multicolumn{3}{|c|}{ Used } & \multicolumn{3}{|c|}{ Unused } & \multirow[t]{2}{*}{$P$} \\
\hline & $\bar{X}$ & SD & $n$ & $\bar{X}$ & $\mathrm{SD}$ & $n$ & & $\bar{X}$ & $\mathrm{SD}$ & $n$ & $\bar{X}$ & $\mathrm{SD}$ & $n$ & & $\bar{X}$ & SD & $n$ & $\bar{X}$ & SD & $n$ & \\
\hline 1 & 1.4 & 2.1 & 26 & 1.2 & 2 & 185 & 0.56 & 0.5 & 1.4 & 26 & 0.5 & 1.4 & 185 & 0.73 & 0.1 & 0.4 & 26 & 0.3 & 1 & 185 & 0.54 \\
\hline 2 & 0.4 & 1.2 & 17 & 0.2 & 0.8 & 76 & 0.21 & 0.6 & 1.2 & 17 & 0.6 & 1.4 & 76 & 0.70 & 0 & 0 & 0 & 0 & 0 & 0 & 0 \\
\hline 3 & 1 & 1.8 & 22 & 0.6 & 1.6 & 782 & 0.20 & 1 & 2 & 22 & 0.6 & 1.5 & 782 & 0.14 & 0.2 & 1.1 & 22 & 0.2 & 0.8 & 782 & 0.89 \\
\hline 4 & 0.9 & 1.8 & 20 & 0.3 & 1.1 & 194 & 0.08 & 0.7 & 1.7 & 20 & 0.6 & 1.5 & 194 & 0.92 & 0.6 & 1.4 & 20 & 0.4 & 1.2 & 194 & 0.67 \\
\hline 5 & 0.5 & 1.4 & 21 & 0.2 & 1 & 359 & 0.10 & 1.1 & 2 & 21 & 0.2 & 0.9 & 359 & $<0.01$ & 0.1 & 0.4 & 21 & 0.3 & 1.1 & 359 & 0.60 \\
\hline 6 & 0 & 0 & 0 & 0 & 0 & 0 & 0 & 2.9 & 2.3 & 18 & 0.8 & 1.7 & 401 & $<0.01$ & 0 & 0 & 18 & 0 & 0.3 & 401 & 0.71 \\
\hline 7 & 0.1 & 0.9 & 34 & 0.1 & 0.5 & 194 & 0.56 & 0 & 0 & 0 & 0 & 0 & 0 & 0 & 0 & 0 & 34 & 0.1 & 0.7 & 194 & 0.26 \\
\hline \multirow[t]{3}{*}{ Owl } & \multicolumn{11}{|c|}{ Hedgerow length } & \multicolumn{10}{|c|}{ Total structure length } \\
\hline & \multicolumn{5}{|c|}{ Used } & \multicolumn{4}{|c|}{ Unused } & \multirow{2}{*}{\multicolumn{2}{|c|}{$P$}} & \multicolumn{4}{|c|}{ Used } & \multicolumn{4}{|c|}{ Unused } & & \multirow[t]{2}{*}{$P$} \\
\hline & $\overline{\mathrm{X}}$ & & SD & $n$ & & $\overline{\mathrm{X}}$ & $\mathrm{SD}$ & & $n$ & & & $\overline{\mathrm{X}}$ & & SD & $n$ & $\bar{X}$ & & SD & $n$ & & \\
\hline 1 & 0 & & 1.4 & 26 & & 0.3 & 1.1 & & 185 & & .19 & 2.6 & & 3.8 & 26 & 2.3 & & 3.6 & 185 & & 0.64 \\
\hline 2 & 0 & & 1.7 & 17 & & 0.4 & 1.2 & & 76 & & 0.10 & 1.5 & & 2.1 & 17 & 1.1 & & 1.8 & 76 & & 0.09 \\
\hline 3 & 0 & & 0 & 22 & & 0.2 & 0.8 & & 782 & & 0.32 & 2.2 & & 2.8 & 22 & 1.5 & & 2.3 & 893 & & 0.18 \\
\hline 4 & 0 & & 1.1 & 20 & & 0.2 & 0.9 & & 194 & & 0.31 & 2.4 & & 3 & 20 & 1.5 & & 2.4 & 194 & & 0.18 \\
\hline 5 & 0 & & 1.4 & 21 & & 0.1 & 0.7 & & 359 & & 0.01 & 2.2 & & 3 & 21 & 0.8 & & 2 & 359 & & $<0.01$ \\
\hline 6 & 0 & & 1.9 & 18 & & 0.2 & 0.8 & & 401 & & 0.01 & 3.5 & & 2.7 & 18 & 1 & & 1.8 & 401 & & $<0.01$ \\
\hline 7 & 0 & & 0 & ( & 0 & 0 & 0 & & 0 & 0 & & 0.1 & & 0.9 & 34 & 0.2 & & 0.9 & 194 & & 0.60 \\
\hline
\end{tabular}

$n$ Number of 1-ha cells, $P$ probability (Wilcoxon-Kruskal Wallis Test); significant difference in bold, trend in bold italics

2005). The ultimate conservation question thus remains how to render these exceptional food reservoirs better exploitable by the owls?

Wildflower areas, canal banks and wood edges were the most species-rich habitat types for small mammals (microrodents and shrews). This may be a result of their diverse vegetation structure, offering a wide range of niches and refuges, compared to monocultures such as arable crops.
The two habitat types that were ploughed in spring (maize and tobacco) were dominated by the two more mobile Apodemus species. Intensive meadows, which are ploughed after a few years, attracted wood mice (A. sylvaticus). Wood edges were dominated by the yellow-necked mice (A. flavicollis). In wildflower areas, canal banks, winter wheat and permanent meadows, voles (Microtus) were the dominant species. Hence, voles mainly build up 
populations in habitats that are not regularly ploughed. In addition, population densities of small mammals appeared to be related to vegetation cover. Mammal densities in habitats with high vegetation cover like wildflower areas, canal bank and wood edges were in all seasons higher than in habitats with low vegetation cover. During July, when the vegetation cover in maize and winter wheat was also well developed, mammal density increased significantly. In September, after harvesting, small mammals had left winter wheat.

The habitat selection analyses showed that foraging activity of breeding Barn Owls was more intense in grassland (very low densities of small mammals) and cereal fields, in agreement with former studies (Mebs and Scherzinger 2000; Roulin 2002). In contrast, wildflower areas were avoided although they represented the best food reservoirs across seasons, followed by canal banks and wood edges. Finally, the availability of cereals and grassland seems to influence both home range size and reproductive performance, i.e. to determine habitat quality.

These results suggest that prey detectability or accessibility may play a crucial role in habitat selection for foraging Barn Owls, as for other raptors (Wakeley 1978; Baker and Brooks 1981; Bechard 1982; Dickman et al. 1991; Jacob and Hempel 2003; Aschwanden et al. 2005, 2007). Open habitats such as cereal fields and grassland are likely to provide an optimal compromise between prey abundance and detectability and/or accessibility. Wildflower areas, with their dense vegetation, are probably not easy to exploit, particularly given that Barn Owls from our study searched for prey almost exclusively on the wing, contrary to findings reported by Taylor (1994). High and dense stalks, or barbed and inflexible plants like teasel Dipsacus fullonum, may hinder raptors from hunting within set-aside and wildflower areas, despite the potentially abundant prey. Similar conclusions have been reached for insectivorous, grassland birds foraging on ground-dwelling prey (Atkinson et al. 2005).

It could be argued that wildflower areas smaller than 0.5 ha would be too small to appear as the dominant habitat type within a 1-ha grid cell, which may lead to erroneous results. This is precisely why we additionally used an alternative approach, for that habitat type only, which consisted in testing the frequency distribution of presenceabsence of wildflower areas and strips between visited and non-visited cells (Table 4). Although we found a difference in only two out of seven owls, both avoided wildflower areas and strips, which further supports the view that this habitat was relatively unattractive for the owls. Of course, wildflower areas may act as source habitats and enhance small mammal numbers in their direct surroundings, but then a positive effect should have been observed in at least one of our analyses. In the end, small mammals may prefer to stay in the dense sward of wildflower areas, possibly to avoid exposure to predators in the surrounding open habitats.

Our results support the findings of Aschwanden et al. (2005) that set-aside and wildflower areas cannot be exploited directly by raptors. However, Aschwanden et al. (2005) observed a preference for grassland adjacent to setaside for Common Kestrels Falco tinnunculus and Longeared Owls Asio otus. We found no such a preference, possibly because wildflower areas in our study area were rarely adjacent to grassland. Grassland is also comparatively rarer in our study area, which harbours more cereal fields, tobacco and vegetable crops.

The apparent avoidance of riparian habitats (where small mammals were abundant) in the compositional analysis may be an artefact; rivers, canals and ditches have a narrow linear structure, and hence rarely appeared as the dominant habitat type within 1-ha cells. The fact that the 1-ha cells visited by 2-3 owls tended to have longer linear structures (streams, hedges, forest edges, etc.) than nonvisited cells suggests that our approach may not have been adequate to estimate the importance of these linear habitats.

In conclusion, although abundance of small mammals was highest in wildflower areas, Barn Owls avoided such habitats while hunting, probably because of low prey accessibility and/or detectability. The exploitation by Barn Owls of these valuable food reservoirs may be facilitated if wildflower areas (and probably also set-aside) were placed along linear landscape features, where the habitat is usually more open and where hunting perches are more numerous (hedges, forest edge, pylons, etc.). Artificial perches could also be placed along wildflower area borders to facilitate hunting by avian predators (Buner 1998). However, given that Swiss Barn Owls seem to hunt mostly on the wing (which may not necessarily result from an absence of perches in the agricultural matrix), a better option for enhancing prey accessibility would be to systematically create open vegetation corridors, of a few metres breadth, within or around wildflower areas. This could, for instance, be achieved by mowing. As shown by Aschwanden et al. (2005), areas where prey is readily accessible (short swards) are preferentially exploited by Kestrels and Longeared Owls. Such open corridors may also temporarily increase local prey accessibility and/or detectability for Barn Owls, especially with regard to common voles which do not usually leave recently mown meadows (Tew and Macdonald 1993; Jacob and Hempel 2003). Experiments with radiotagged owls could be conducted to test if these measures were appropriate, i.e. if they could increase foraging habitat suitability and owls' hunting efficiency. If so, agricultural policies could promote new management practices of wildflower areas (and by extension set-aside 
and fallowland) for the attribution of subsidies to farmers. With their outstanding density of small mammals, wildflower areas have a huge potential for reinstating integral food chains within agro-ecosystems; there is, however, some further effort to consent for enhancing the accessibility of these fantastic food reservoirs so as to benefit in turn their principal avian predators.

\section{Zusammenfassung}

Buntbrachen in revitalisiertem Agrarland fördern Populationen von Kleinsäugern, aber nicht von Schleiereulen

Wegen der intensiven Nutzung hat die Biodiversität in Agrarökosystemen in den letzten Jahren dramatisch abgenommen. Um die Biodiversität wieder zu erhöhen, werden Landwirte nun finanziell unterstützt, wenn sie ökologische Ausgleichsflächen anlegen. Mehrere Studien haben gezeigt, dass die Arthropodenvielfalt in solchen Ausgleichsflächen höher ist, als im angrenzenden, konventionell genutzten Agrarland. Bisher war aber wenig untersucht, wie weit sich Ausgleichflächen auch auf Wirbeltierpopulationen, und somit auf Tiere einer höheren trophischen Ebene, positiv auswirken. Wir untersuchten die Populationsdichten von Kleinsäugern in 8 verschiedenen Habitattypen (darunter Buntbrachen), und die Nutzung dieser Habitattypen durch Schleiereulen Tyto alba. Wir erwarteten, dass Schleiereulen Habitate mit einer großen Kleinsäugerdichte häufiger zur Nahrungssuche aufsuchen würden, als Habitate mit geringen Kleinsäugerdichten. Buntbrachen wiesen die deutlich höchsten Kleinsäugerdichten auf. Schleiereulen jagten jedoch bevorzugt über Getreidefeldern und Grünland. Sie vermieden alle Ackerflächen (außer Getreide) wie auch Buntbrachen, was zeigt, dass sie ihr Nahrungssuchverhalten nicht primär nach der Nahrungsdichte ausrichteten. Anstatt der Nahrungsdichte, dürfte die Nahrungszugänglichkeit viel entscheidender sein: Buntbrachen weisen eine dichte Vegetationsstruktur auf, was die Zugänglichkeit zu Kleinsäugern erschwert. Buntbrachen könnten für Schleiereulen dennoch attraktive Habitate werden, wenn offene, vegetationsarme Flächen innerhalb oder um die Buntbrachen geschaffen würden. Auf diese Weise könnten Buntbrachen dazu beitragen, dass Nahrungsketten in Agrarökosystemen bis $\mathrm{zu}$ höheren trophischen Stufen wieder funktionieren.

Acknowledgments We are grateful to Adrian Aebischer, JeanPierre Airoldi, Janine Aschwanden, Iris Baumgartner, Julien Béguin, Otto Holzgang, Alan Juilland, Olivier Roth and Christine Wisler for their assistance. Special thanks also to the farmers who authorised captures on their land and to Juliet Vickery for corrections of the English of an earlier version of the manuscript and for constructive criticism.

\section{Appendix}

See Table 6.

Table 6 Population sizes of small mammals estimated with program CAPTURE (Otis et al. 1978) recorded in May, July and September, in eight habitat types and at four capture sites each

\begin{tabular}{|c|c|c|c|c|}
\hline Month & Habitat type & Site & $\begin{array}{l}\text { Best } \\
\text { model }\end{array}$ & $\begin{array}{l}\text { Estimated } \\
\text { population } \\
\text { size }\end{array}$ \\
\hline \multirow[t]{32}{*}{ May } & \multirow[t]{4}{*}{ Wildflower area } & Site 1 & $\mathrm{M}(\mathrm{o})$ & $16(3.7)$ \\
\hline & & Site 2 & $\mathrm{M}(\mathrm{o})$ & $26(5.2)$ \\
\hline & & Site 3 & $\mathrm{M}(\mathrm{o})$ & $25(6.5)$ \\
\hline & & Site 4 & $\mathrm{M}(\mathrm{o})$ & $84(22.7)$ \\
\hline & \multirow[t]{4}{*}{ Canal bank } & Site 1 & $\mathrm{M}(\mathrm{o})$ & $18(9.0)$ \\
\hline & & Site 2 & $\mathrm{M}(\mathrm{h})$ & $23(5.1)$ \\
\hline & & Site 3 & $\mathrm{M}(\mathrm{tb})$ & $27(0.0)$ \\
\hline & & Site 4 & NA & 3 \\
\hline & \multirow[t]{4}{*}{ Wood edge } & Site 1 & NA & 1 \\
\hline & & Site 2 & $\mathrm{M}(\mathrm{o})$ & $36(10.5)$ \\
\hline & & Site 3 & $M(t)$ & $23(1.7)$ \\
\hline & & Site 4 & NA & 0 \\
\hline & \multirow[t]{4}{*}{ Winter wheat } & Site 1 & NA & 1 \\
\hline & & Site 2 & $\mathrm{M}(\mathrm{th})$ & $14(4.0)$ \\
\hline & & Site 3 & No model & 3 \\
\hline & & Site 4 & $\mathrm{M}(\mathrm{h})$ & $14(4.1)$ \\
\hline & \multirow[t]{4}{*}{ Maize } & Site 1 & NA & 0 \\
\hline & & Site 2 & NA & 0 \\
\hline & & Site 3 & NA & 0 \\
\hline & & Site 4 & NA & 0 \\
\hline & \multirow[t]{4}{*}{ Tobacco } & Site 1 & NA & 0 \\
\hline & & Site 2 & NA & 0 \\
\hline & & Site 3 & NA & 0 \\
\hline & & Site 4 & NA & 0 \\
\hline & \multirow[t]{4}{*}{ Permanent meadow } & Site 1 & NA & 1 \\
\hline & & Site 2 & NA & 1 \\
\hline & & Site 3 & NA & 1 \\
\hline & & Site 4 & NA & 2 \\
\hline & \multirow[t]{4}{*}{ Intensive meadow } & Site 1 & NA & 1 \\
\hline & & Site 2 & NA & 0 \\
\hline & & Site 3 & NA & 0 \\
\hline & & Site 4 & NA & 0 \\
\hline \multirow[t]{8}{*}{ July } & \multirow[t]{4}{*}{ Wildflower area } & Site 1 & $\mathrm{M}(\mathrm{o})$ & $64(10.4)$ \\
\hline & & Site 2 & $\mathrm{M}(\mathrm{t})$ & $81(5.8)$ \\
\hline & & Site 3 & $\mathrm{M}(\mathrm{th})$ & $79(7.7)$ \\
\hline & & Site 4 & $M(t)$ & $116(86.0)$ \\
\hline & \multirow[t]{4}{*}{ Canal bank } & Site 1 & NA & 1 \\
\hline & & Site 2 & $\mathrm{M}(\mathrm{t})$ & $74(3.8)$ \\
\hline & & Site 3 & $\mathrm{M}(\mathrm{o})$ & $28(2.5)$ \\
\hline & & Site 4 & NA & 2 \\
\hline
\end{tabular}


Table 6 continued

\begin{tabular}{|c|c|c|c|c|}
\hline Month & Habitat type & Site & $\begin{array}{l}\text { Best } \\
\text { model }\end{array}$ & $\begin{array}{l}\text { Estimated } \\
\text { population } \\
\text { size }\end{array}$ \\
\hline & Wood edge & Site 1 & $\mathrm{M}(\mathrm{h})$ & $77(11.5)$ \\
\hline & & Site 2 & $\mathrm{M}(\mathrm{b})$ & $5(0.4)$ \\
\hline & & Site 3 & NA & 1 \\
\hline & & Site 4 & $\mathrm{M}(\mathrm{o})$ & $7(5.0)$ \\
\hline & Winter wheat & Site 1 & $\mathrm{M}(\mathrm{o})$ & $40(16.1)$ \\
\hline & & Site 2 & $\mathrm{M}(\mathrm{t})$ & $55(6.1)$ \\
\hline & & Site 3 & $\mathrm{M}(\mathrm{th})$ & $18(8.3)$ \\
\hline & & Site 4 & $\mathrm{M}(\mathrm{t})$ & $114(67.8)$ \\
\hline & Maize & Site 1 & NA & 2 \\
\hline & & Site 2 & $\mathrm{M}(\mathrm{h})$ & $26(6.9)$ \\
\hline & & Site 3 & NA & 0 \\
\hline & & Site 4 & $\mathrm{M}(\mathrm{h})$ & $36(10.5)$ \\
\hline & Tobacco & Site 1 & NA & 2 \\
\hline & & Site 2 & NA & 0 \\
\hline & & Site 3 & NA & 0 \\
\hline & & Site 4 & NA & 1 \\
\hline & Permanent meadow & Site 1 & NA & 0 \\
\hline & & Site 2 & NA & 4 \\
\hline & & Site 3 & NA & 1 \\
\hline & & Site 4 & NA & 1 \\
\hline & Intensive meadow & Site 1 & NA & 0 \\
\hline & & Site 2 & NA & 0 \\
\hline & & Site 3 & NA & 1 \\
\hline & & Site 4 & NA & 2 \\
\hline \multirow[t]{20}{*}{ September } & Wildflower area & Site 1 & NA & 0 \\
\hline & & Site 2 & $\mathrm{M}(\mathrm{th})$ & $163(21.4)$ \\
\hline & & Site 3 & $\mathrm{M}(\mathrm{th})$ & $122(11.1)$ \\
\hline & & Site 4 & $\mathrm{M}(\mathrm{tbh})$ & $139(14.4)$ \\
\hline & Canal bank & Site 1 & $\mathrm{M}(\mathrm{o})$ & $11(8.4)$ \\
\hline & & Site 2 & $\mathrm{M}(\mathrm{th})$ & $123(14.1)$ \\
\hline & & Site 3 & $\mathrm{M}(\mathrm{t})$ & $77(14.5)$ \\
\hline & & Site 4 & NA & 0 \\
\hline & Wood edge & Site 1 & $\mathrm{M}(\mathrm{o})$ & $26(5.2)$ \\
\hline & & Site 2 & $\mathrm{M}(\mathrm{th})$ & $81(16.1)$ \\
\hline & & Site 3 & $\mathrm{M}(\mathrm{tb})$ & 15 \\
\hline & & Site 4 & $\mathrm{M}(\mathrm{o})$ & $10(2.7)$ \\
\hline & Winter wheat & Site 1 & NA & 0 \\
\hline & & Site 2 & NA & 0 \\
\hline & & Site 3 & NA & 0 \\
\hline & & Site 4 & NA & 0 \\
\hline & Maize & Site 1 & NA & 1 \\
\hline & & Site 2 & $\mathrm{M}(\mathrm{t})$ & $28(2.3)$ \\
\hline & & Site 3 & NA & 3 \\
\hline & & Site 4 & NA & 5 \\
\hline
\end{tabular}

Table 6 continued

\begin{tabular}{|c|c|c|c|c|}
\hline Month & Habitat type & Site & $\begin{array}{l}\text { Best } \\
\text { model }\end{array}$ & $\begin{array}{l}\text { Estimated } \\
\text { population } \\
\text { size }\end{array}$ \\
\hline & \multirow{4}{*}{ Tobacco } & Site 1 & $\mathrm{M}(\mathrm{o})$ & $16(12.7)$ \\
\hline & & Site 2 & NA & 0 \\
\hline & & Site 3 & NA & 0 \\
\hline & & Site 4 & NA & 0 \\
\hline & \multirow[t]{4}{*}{ Permanent meadow } & Site 1 & NA & 1 \\
\hline & & Site 2 & NA & 3 \\
\hline & & Site 3 & NA & 0 \\
\hline & & Site 4 & NA & 0 \\
\hline & \multirow[t]{4}{*}{ Intensive meadow } & Site 1 & NA & 1 \\
\hline & & Site 2 & NA & 0 \\
\hline & & Site 3 & NA & 0 \\
\hline & & Site 4 & $\mathrm{M}(\mathrm{h})$ & $10(2.7)$ \\
\hline
\end{tabular}

The best selected model is given as well as the estimated population size (standard error in parentheses): $M(o)$ capture probability constant; $M(t)$ capture probability time-dependent; $M(b)$ capture and recapture probability different (behavioural effect); $M(h)$ individual differences in capture probability; $M(t b)$ time and behavioural effects on capture probability; $M(t h)$ time and individual effects in capture probability; $M(t h b)$ time, behavioural and individual effects on capture probability; $N A$ not applicable as no recaptures obtained. Note that if no individual was recaptured (NA), we report the number of individuals that have been captured

\section{References}

Aebischer NJ, Robertson PA, Kenward RE (1993) Compositional analysis of use from animal radio-tracking data. Ecology 74:13131325

Altwegg R, Roulin A, Kestenholz M, Jenni L (2003) Variation and covariation in survival, dispersal, and population size in barn owls Tyto alba. J Anim Ecol 72:391-399

Altwegg R, Roulin A, Kestenholz M, Jenni L (2006) Demographic effects of extreme winter weather in the barn owl. Oecologica 149:44-51

Altwegg R, Schaub M, Roulin A (2007) Age-specific fitness components and their temporal variation in the barn owl. Am Nat 169:47-61

Arlettaz R (1999) Habitat selection as a major resource portioning mechanism between the two sympatric sibling bat species Myotis myotis and Myotis blythii. J Anim Ecol 68:460-471

Aschwanden J, Birrer S, Jenni L (2005) Are ecological compensation areas attractive hunting sites for common kestrels (Falco tinnunculus) and long-eared owls (Asio otus)? J Ornithol 146:279-286

Aschwanden J, Holzgang O, Jenni L (2007) Importance of ecological compensation areas for small mammals in intensively farmed areas. Wildl Biol 13:150-158

Askew NP, Searle JB, Moore NP (2007) Agri-environment schemes and foraging of barn owls Tyto alba. Agric Ecosyst Environ 118:109-114

Atkinson PW, Fuller RJ, Vickery JA, Conway GJ, Tallowin JRB, Smith REN, Haysom KA, Ings TC, Asteraki EJ, Brown VK (2005) Influence of agricultural management, sward structure 
and food resources on grassland field use by birds in lowland England. J Appl Ecol 42:932-942

Baker JA, Brooks RJ (1981) Distribution patterns of raptors in relation to density of meadow voles. Condor $83: 42-47$

Bechard MJ (1982) Effect of vegetative cover on foraging site by Swainson's hawk. Condor 84:153-159

Benton TG, Vickery JA, Wilson JD (2003) Farmland biodiversity: is habitat heterogeneity the key? Trends Ecol Evol 18:182-188

Birrer S, Spiess M, Herzog F, Jenny M, Kohli L, Lugrin B (2007) The Swiss agri-environment scheme promotes farmland birds: but only moderately. J Ornithol 148:S295-S303

Briner T, Nentwig W, Airoldi J-P (2005) Habitat quality of wildflower strips for common voles (Microtus arvalis) and its relevance for agriculture. Agric Ecosyst Environ 105:173179

Britschgi A, Spaar R, Arlettaz R (2006) Impact of grassland farming intensification on the breeding ecology of an indicator insectivorous passerine, the Whinchat Saxicola rubetra: lessons for overall Alpine meadowland management. Biol Conserv 130:193205

Buner F (1998) Habitat use of wintering Kestrels (Falco tinnunculus) in relation to perch availability, vole abundance and spatial distribution. Diploma Thesis, University of Basel, Swiss Ornithological Institute Sempach

Burkhardt M, Schmid H (2001) Vögel der Schweiz. Schweizerische Vogelwarte, Sempach

Dickman CR, Predavec M, Lynam AJ (1991) Differential predation of size and sex classes of mice by the barn owl, Tyto alba. Oikos 62:67-76

Donald PF, Green RE, Heath MF (2001) Agricultural intensification and the collapse of Europe's farmland bird populations. Proc R Soc Lond B 268:25-29

Estabrook CB, Estabrook GF (1989) Actus: a solution to the problem of small samples in the analysis of two-way contingency tables. Hist Methods 82:5-8

Gilg O, Hanski I, Sittler B (2003) Cyclic dynamics in a simple vertebrate predator-prey community. Science 302:866-868

Gilg O, Sittler B, Sabard B, Hurstel A, Sané R, Delattre P, Hanski I (2006) Functional and numerical responses of four lemming predators in higharctic Greenland. Oikos 113:193-216

Hansson L, Henttonen H (1988) Rodent dynamics as community processes. Trends Ecol Evol 3:195-200

Jacob J, Hempel N (2003) Effects of farming practices on spatial behaviour of common voles. J Ethol 21:45-50

Kleijn D, Sutherland WJ (2003) How effective are European agrienvironmental schemes in conserving and promoting biodiversity? J Appl Ecol 40:947-969

Kleijn D, Berendse F, Smit R, Gillissen N (2001) Agri-environment schemes do not effectively protect biodiversity in Dutch agricultural landscapes. Nature 413:723-725

Kleijn D, Baquero RA, Clough Y, Diaz M, De Esteban J, Fernandez F, Gabriel D, Herzog F, Holzschuh A, Jöhl R, Knowp E, Kruess A, Marshall EJP, Steffan-Dewenter I, Tscharntke T, Verhulst J, West TM, Yela JL (2006) Mixed biodiversity benefits of agrienvironment schemes in five European countries. Ecol Lett 9:243-254

Knop E, Kleijn D, Herzog F, Schmid B (2006) Effectiveness of the Swiss agri-environment scheme in promoting biodiversity. J Appl Ecol 43:120-127

Korpimäki E (1994) Rapid or delayed tracking of multi-annual vole cycles by avian predators? J Anim Ecol 63:619-628

Korpimäki E, Norrdahl K (1991) Numerical and functional responses of kestrels, short-eared owls, and long-eared owls to vole densities. Ecology 72:814-826
MacDonald DW, Tattersall FH, Service KM, Firbank LG, Feber RE (2007) Mammals, agri-environment schemes and set-asidewhat are the putative benefits? Mammal Rev 37:259-277

Mebs T, Scherzinger W (2000) Die Eulen Europas. Kosmos, Stuttgart

Mohr CO (1947) Table of equivalent populations of North American small mammals. Am Midl Nat 37:223-249

Nentwig W (2000) Streifenförmige ökologische Ausgleichsflächen in der Kulturlandschaft: Ackerkrautstreifen, Buntbrache, Feldränder. Agrarökologie, Bern, p 293

Otis DL, Burnham KP, White GC, Anderson DR (1978) Statistical inference from capture data on closed animal populations. Wildl Monogr 62:1-135

Palma L, Beja P, Pais M, Cancela da Fonseca L (2006) Why do raptors take domestic prey? the case of Bonelli's eagles and pigeons. J Appl Ecol 43:1075-1086

Reid K, Croxall JP (2001) Environmental response of upper trophiclevel predators reveals a system change in an Antarctic marine ecosystem. Proc R Soc Lond B 268:377-384

Reid N, McDonald RA, Montgomery WI (2007) Mammals and agrienvironment schemes: hare haven or pest paradise? J Appl Ecol 44:1200-1208

Revaz E, Schaub M, Arlettaz R (2008) Foraging ecology and reproductive biology of the Stonechat Saxicola torquata: comparison between a revitalized, intensively cultivated and a historical, traditionally cultivated agro-ecosystem. J Ornithol 149:301-312

Roulin A (1999) Natural and experimental nest-switching in Barn Owl Tyto alba fledglings. Ardea 87:237-246

Roulin A (2002) Tyto alba Barn Owl. BWP Update 4(2):115-138

Roulin A, Riols C, Dijkstra C, Ducrest A-L (2001) Female- and malespecific signals of quality in the barn owl. J Evol Biol 14:255-267

Schmid B (2002) The species richness-productivity controversy. Trends Ecol Evol 17:113-114

Schmid H, Luder R, Naef-Daenzer B, Graf R, Zbinden N (1998) Schweizer Brutvogelatlas. Verbreitung der Vögel in der Schweiz und im Fürstentum Liechtenstein 1993-1996. Schweizerische Vogelwarte, Seampach

Schweizer Eidgenossenschaft (1998) Verordnungen über die Direktzahlungen an die Landwirtschaft 910.13, 3. Titel, 1. Kapitel, 16-24

Shore RF, Meek WR, Sparks TH, Pywell RF, Nowakowski M (2005) Will Environmental Stewarship enhance small mammal abundance on intensively managed farmland? Mammal Rev 35:277-284

Snow DW, Perrins CM (1998) The birds of the western palearctic, concise edition, vol I. Oxford University Press, Oxford, pp 886888

Tattersall FH, Macdonald DW, Manley WJ, Gates S, Feber R, Hart BJ (1997) Small mammals on one-year set-aside. Acta Theriol 42:329-334

Tattersall FH, Avundo AE, Manley WJ, Hart BJ, Macdonald DW (2000) Managing set-aside for field voles (Microtus agrestis). Biol Conserv 96:123-128

Taylor IR (1994) Barn owls: predator-prey relationships. Cambridge University Press, Cambridge

Tew TE, Macdonald DW (1993) The effects of harvest on arable wood mice Apodemus sylvaticus. Biol Conserv 65:279-283

Veit RR, Silverman ED, Everson I (1993) Aggregation patterns of pelagic predators and their principal prey, antarctic krill, near South Georgia. J Anim Ecol 62:551-564

Wakeley JS (1978) Factors affecting the use of hunting sites by Ferruginous hawks. Condor 80:316-326

White GC, Garrot RA (1990) Analysis of wildlife radiotracking data. Academic, San Diego, p 383

Whitthingham MJ (2007) Will agri-environment schemes deliver substantial biodiversity gain, and if not why? J Appl Ecol 44:1-5 